Ewa OgrodzKa-Mazur, AnNA SZAFrańSKa

University of Silesia

in Katowice

Josef Malach, Milan Chmura

University of Ostrava

\title{
A STIMULATING THE LEARNING OF POLISH AND CZECH STUDENTS WITH THE USE OF E-LEARNING RESOURCES
}

\begin{abstract}
Ogrodzka-Mazur Ewa, Szafrańska Anna, Malach Josef, Chmura Milan, A Stimulating the Learning of Polish and Czech Students with the Use of e-Learning Resources [Stymulacja nauki uczniów polskich i czeskich za pomocą narzędzi e-learningowych]. Studia Edukacyjne nr 50, 2018, Poznań 2018, pp. 213-228. Adam Mickiewicz University Press. ISSN 1233-6688. DOI: 10.14746/se.2018.50.14
\end{abstract}

The article is a result of the collaboration between Polish and Czech scientists who explore academic teachers' application of resources from the e-learning environment. The presented studies were conducted in 2015-2016 within the IRNet project - International research network for study and development of new tools and methods for advanced pedagogical science in the field of ICT instruments, e-learning and intercultural competences in Poland (University of Silesia in Katowice, Faculty of Ethnology and Educational Science in Cieszyn) and the Czech Republic (University of Ostrava, Pedagogical Faculty). The research was aimed at learning the opinions of academic teachers on their preparation for distance classes and for the stimulation of students' learning process. The research applied a constructivist perspective, which highlighted the learner's activity resulting in the subject building their educational reality (in the educational process). Due to the comparative nature of the research, it invoked Harold J. Noah's model of comparing the quality of University education. The text discusses cases of Poland and the Czech Republic.

Key words: upper education didactics, academic teachers, stimulation of the learning process, e-learning resources, comparative studies

...if we teach today as we taught yesterday, we rob our children of tomorrow

John Dewey

\section{Introduction}

The sociocultural and economic changes which are taking place currently largely determine the educational space - including the space of universities. 
The changes occurring in the Central and Eastern Europe after 1989 have been reflected in the way in which higher education schools function in this region. The opening to new technologies, training the teaching staff, the possibilities of using European funds, which allow for modernization of the existing teaching base, are just a few determinants of the transformations in this field.

Contemporary education at the level of university studies is implemented with the application of various methods, which are often supported by new technologies. What seems a particular enhancer in this field is e-learning, which facilitates the individualization of the educational process. At the same time, it is the attachment to traditional methods and forms of teaching which dominates among the teaching staff. In the traditional model of education, the teacher effortlessly organizes personalized groups and establishes direct contacts with students. In the education via e-learning, the teacher has to initiate the conditions for mutual recognition, communication, joint collaborative activities. It is the teacher who establishes the principles of communication and enforces them. ${ }^{1}$

It is predicted that the world need for university education will be growing in geometric progression: from 100 million students now to 250 million in 2025. A substantial percentage of this increase are learning adults or people who return to university studies, forming a diversified group, the majority of which both study and work. This prognosis gives rise to several important questions: Will the institutions of higher education in Europe and worldwide be able to maintain and improve the quality of education in the conditions of a permanent increase and diversification of students' population? In what way do these institutions have to adjust and at the same time transform to fulfil the new quality of students' needs? To what extent do (and will) the demand for open approaches and educational resources as well as the development of learning techniques with the use of modern technologies modify education at the higher level? ${ }^{2}$

The use of distant learning is also becoming very popular in Poland and the Czech Republic. Therefore, our interest was to find out how the process of learning-teaching was stimulated by e-learning tools. The analyses presented in this article are a fragment of broader research implemented by the Polish-Czech team in 2015-2016 within the international project IRNET - International research network for study and development of new tools and methods for advan-

${ }^{1}$ W. Sołtysiak, Wybrane metody ksztatcenia stosowane w e-learningu akademickim [Selected educational methods applied in academic e-learning], Podstawy Edukacji, 2014, 7, p. 383.

2 Report to the European Commission on New modes of learning and teaching in higher education, Luxembourg 2014, p. 14-15; K. Illeris, Towards a contemporary and comprehensive theory of learning, International Journal of Lifelong Learning, 2003, 22, 4, p. 396-406; A. Ryan, D. Tilbury, Flexible Pedagogies: preparing for the future, New York 2013, p. 4-6. 
ced pedagogical science in the field of ICT instruments, e-learning and intercultural competences. What has been indicated in some earlier texts are the differences in intercultural and IT competences of Polish and Czech university students. ${ }^{3}$ Our analyses also have helped to answer whether there are (and if so what are) the differences in the way academic teachers make use of modern technologies. ${ }^{4}$

In another text, the focus was on the results of exploring the purposes of using digital tools to support student learning at universities. This comprised distinguishing some types of digital tools and the frequency of their use by academic staff, which differs due to their level of digital literacy. ${ }^{5}$

\section{Theoretical and methodological assumptions}

In the expert literature, two opposing educational models are distinguished in the approach of academic teachers and students to e-learning activity:

- educational contents are focused on,

- the student's cognitive activity is focused on.

The first model, which represents the lecturing mode of teaching, derives from the behavioural concept according to which the teacher indicates, initiates and conducts the whole teaching - learning course. The second model comes from the constructivist paradigm, which assumes self-education and interaction between the main actors of the educational process. The learner makes use of the resources available within the course and explores internet resources. Students make their selection, create new resources of knowledge in collaboration with other participants, make their own media statements, use the tools of the platform, e.g. electronic mail, discussion forums, messengers and other tools aimed at communication. ${ }^{6}$

${ }^{3}$ A. Gajdzica et al., Research into students' ICT competencies and their use in ICT at selected universities. A Polish-Czech comparative study, Studia Edukacyjne, 2015, 36, p. 365-379.

${ }^{4}$ E. Ogrodzka-Mazur et al., The use of e-learning resources by academic teachers - a Polish-Czech comparative study, The New Educational Review, 2017, 50, 4, p. 169-185.

${ }^{5}$ E. Ogrodzka-Mazur et al., Supporting the learning of Polish and Czech students by digital tools, The New Educational Review, 2018, 51, 1.

${ }^{6}$ W. Sołtysiak, Determinanty aktywności studentów w kontekście ksztatcenia e-learningowego [Determinants of students' activeness in the context of e-learning], Zeszyty Naukowe Politechniki Częstochowskiej. Zarządzanie, 2016, 1, 23, p. 150; D. Jelonek, A. Nowicki, L. Ziora, The Application of e-Learning in the Didactic Process at the Faculty of Management in Czestochowa University of Technology, Organization, Tools, Model, in Cohen, [in:] Proceedings of Informing Science \& IT Education Conference (InSITE), Ed. E. Boyd, California 2014, p. 143-156; D. Koller, What We're Learning from Online Education? 2012, http://www.ted.com/talks/daphne_koller_what_we_re_learning_from_online_education [access: 15.03.2018]. 
In the undertaken studies, the constructivist perspective was applied, which emphasizes the learner's activity in the educational process - this activity results in subjects' building their reality. Learners actively construct their knowledge and they do not acquire it as provided by teachers, because people are not recorders of information but the constructors of their own knowledge. ${ }^{7}$ This way of understanding education is deeply rooted in the thought of John Dewey, Lev Vygotsky, George Kelly, as well as in Jerome Bruner's theory of personal constructs, which treats knowledge as a form of intellectual representation, as a construct of human mind. ${ }^{8}$ This approach seems particularly useful in the interpretation of academic teachers' research activity, as well as their didactic activity supported by information and communication technologies.

Due to the comparative nature of the research, Harold J. Noah's model of comparing the quality of university education was referred to. ${ }^{9}$ The cases of Poland and the Czech Republic were discussed, taking into consideration the description of the traditions and newest tendencies concerning higher education in both countries, the analysis of university curricula in the field of ICT, the socio-economic and cultural contexts, the interpretation of educational phenomena which can become predictors of changes, and statistical methods. ${ }^{10}$

At the end of the 2015/2016 academic year, the collecting of data from the questionnaire research among academic scholars was carried out. The aim of the questionnaire research was to present the real picture of the current situation concerning university teachers' opinions on online education and the current situation concerning the use of the basic components of the university electronic environment for educational purposes.

The main research problem was not being familiarized with academic scholars' opinions on the instruments ensuring online education and the absence of relevant data concerning their actual usage in the educational process and for managed self-education of students.

The studies were conducted in 2015-2016 within the IRNet project in Poland, University of Silesia, Faculty of Ethnology and Education in Cieszyn, and in the Czech Republic, University of Ostrava, Pedagogical Faculty.

${ }^{7}$ J. Qvortrup, Childhood as a Structural Form, [w:] The Palgrave Handbook of Childhood Studies, red. J. Qvotrup, W.A. Corsaro, M.-S. Honig, Basingstoke 2009.

${ }^{8}$ B.L. Shapiro, What children bring to light. A constructivism perspective on children's learning in science, New York 1994, p. 3.

${ }_{9}$ Noah H.J., Eckstein M.A., Dependency Theory in Comparative Education: Twelve Lessons from the Literature, [in:] Theories and Methods in Comparative Education, Eds. J. Schriewer, B. Holmes, Frankfurt am Main 1988, p. 165-192; J. Marshall, Introduction to Comparative and International Education, Los Angeles - London - New Delhi - Singapore - Washington 2014.

${ }_{10} \mathrm{~J}$. Malach et al., Social media at Czech and Polish universities: a comparative study, International Journal of Information and Communication Technologies in Education, 2016, 5, 1, p. 41-58. 
The Faculty of Ethnology and Educational Science conducts research tasks in the field of pedagogy and ethnology. The Faculty educates 2000 students of pedagogy. The process of academic education comprises such academic subjects as e.g. multi- and intercultural education, computer science and information technology. Students make use of the faculty distance learning platform, based on the MOODLE system, which enhances future teachers' preparation for applying e-learning in their work and for undertaking the function of a tutor.

The studies comprised 46 academic teachers, including $30.4 \%$ of full-time professors, $39.2 \%$ of assistant professors and $30.4 \%$ of assistants.

Currently, the Faculty of Education of the University of Ostrava has almost 2300 students. Most of the subjects are pedagogy-oriented and dominated by disciplines aimed at future teachers training; subjects are taught in bachelor, master and doctoral courses by 107 academic scholars. The Faculty has the MOODLE system, electronic informational databases and modern, well-equipped lecture theatres, with smart boards.

The research involved 40 university teachers working at the Pedagogical Faculty of the University of Ostrava, 26 of which were men $(65 \%)$ and 14 women $(35 \%) .38 \%$ of the entire number of 106 academic scholars working at the Faculty participated in the research. The majority of respondents were assistant professors (72.5\%), the rest were doctors with habilitation and full-time professors. The majority of them were aged $41-50$ (35\%) and $31-40(25 \%)$, while $62.5 \%$ of the respondents were no older than 50 . As far as the level of ICT use is concerned, $7.5 \%$ of the respondents considered themselves beginners, $62.5 \%$ considered themselves intermediate and 30\% advanced users. The questionnaire was sent via email to all 106 teachers of the Pedagogical Faculty of the University of Ostrava. They were asked to fill it in the Google environment. It was up to the addressed teachers whether or not they wanted to participate in the research. Therefore, it can be said that the selection of respondents was random.

\section{Stimulating students' learning - research results}

In the organization of the didactic process, one key aspect concerning students should be taken into consideration. What seems of crucial importance is the way in which knowledge is passed down and the ensuring of necessary conditions which will make a student participate actively in the process of passing this knowledge and the related information. ${ }^{11}$

${ }^{11}$ M.G. Moore, W.G. Anderson (Eds.), Handbook of distance education, London 2003; A. Gajdzica et al., Research into students' ICT competencies, p. 365-379; A. Powell et al., iNACOL Blending 
The respondents in the Czech Republic were asked to choose the instruments which they use if they want to change the trajectory of students' study activities. They could choose more than one of the six possible answers. In University of Ostrava, the majority of teachers do not use electronic instruments for the aforementioned purpose (62.5\% of all teachers). $30 \%$ of all teachers stated that they use individual student portfolios within the course. Every eighth teacher uses the individual portfolio within students' study or social interests and every tenth teacher uses the individual portfolio within the educational process. However, the differences in the three types of portfolios were not specified to the teachers. As a result, it could happen that the teachers could not notice the differences. If we merged the use of the three types of portfolios into one group of answers, it would be used by more than $40 \%$ of all teachers $(42.9 \%)$.

A number of hypotheses were being verified concerning the relation of answers to this question and the remaining parts of the questionnaire. However, no relation was found between any of the positive answers and the fact that the teachers participate in social networks. Moreover, no other criteria influence the respondents' answers to this question.

The responses of scholars from Cieszyn are different in this respect (cf. Tab. 1 and Fig. 1). Similarly (as regards the determining factor - environment) to their colleagues from Ostrava, they stimulate students' learning with the use of:

- student portfolio within the educational process $-21.7 \%\left(\chi^{2}=2.2 ; \mathrm{p}=\right.$ $0.14>\mathrm{p}=0.05$ and $\Phi=0.16)$,

- other $-0.0 \%\left(x^{2}=1.2 ; p=0.47>p=0.05\right.$ and $\left.\Phi=0.12\right)$.

Table 1 Instruments used by teachers to change the trajectory of students' study activities (factor - environment)

\begin{tabular}{|l|c|c|c|c|c|c|}
\hline \multirow{2}{*}{ Items } & \multicolumn{2}{|c|}{ Frequency } & \multicolumn{2}{c|}{$\begin{array}{c}\text { Percentage } \\
\text { of teachers }\end{array}$} & \multicolumn{2}{c|}{ Percentage of cases } \\
\cline { 2 - 7 } & Czech R. & Poland & Czech R. & Poland & Czech R. & Poland \\
\hline I do not use any & 25 & 8 & 62.5 & 17.4 & 51.0 & 9.1 \\
\hline $\begin{array}{l}\text { Student portfolio } \\
\text { within the course }\end{array}$ & 12 & 26 & 30.0 & 56.5 & 24.5 & 29.5 \\
\hline $\begin{array}{l}\text { Student portfolio } \\
\text { within their inte- } \\
\text { rests }\end{array}$ & 5 & 16 & 12.5 & 34.8 & 10.2 & 18.2 \\
\hline
\end{tabular}

Learning Teacher Competency Framework 2015 http:/ / www.inacol.org/resource/inacol-blended-learning-teacher-competency-framework/ [access: 15.03.2018]. 


\begin{tabular}{|l|c|c|c|c|c|c|}
\hline $\begin{array}{l}\text { Student portfolio } \\
\text { within the educa- } \\
\text { tional process }\end{array}$ & 4 & 10 & 10.0 & 21.7 & 8.2 & 11.4 \\
\hline Electronic register & $\mathbf{2}$ & $\mathbf{2 8}$ & $\mathbf{5 . 0}$ & $\mathbf{6 0 . 9}$ & $\mathbf{4 . 1}$ & $\mathbf{3 1 . 8}$ \\
\hline Other & 1 & 0 & 2.5 & 0.0 & 2.0 & 0.0 \\
\hline Total & 49 & 88 & 122.5 & 156.9 & 100.0 & 100.0 \\
\hline
\end{tabular}

* In all figures and tables, statistically significant differences are marked in bold.

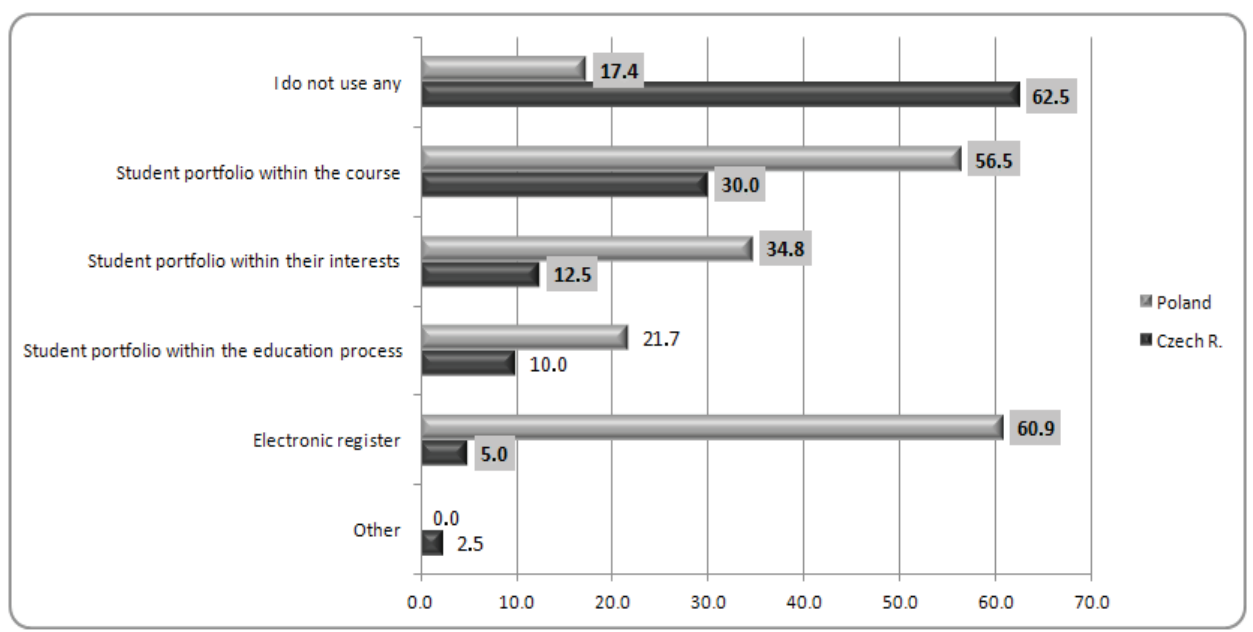

Fig. 1. Instruments used by teachers to change the trajectory of students' study activities (factor - environment)

Source: own elaboration

In the other cases, the answers of Polish academic teachers significantly differ in the following categories:

- I do not use any - 17.4\% ( $\chi 2=18.4 ; p=0.000$ and $\Phi=0.46)$,

- student portfolio within the course $-56.5 \%\left(\chi^{2}=6.1 ; p=0.01\right.$ and $\Phi=0.27$,

- student portfolio within their interests $-34.8 \%\left(\chi^{2}=5.8 ; p=0.02\right.$ and $\Phi=0.26)$,

- electronic register $-60.9 \% ;(\chi 2=29.4 ; p=0.000$ and $\Phi=0.58)$.

The academic staff from both universities chose the form of network communication with students which these students preferred in the educational process. The results are summarized in Table 2 and Figure 2, respectively. 
Table 2

Teachers' preferred ways of electronic communication with their students

(factor - environment)

\begin{tabular}{|l|c|c|c|c|c|c|}
\hline \multirow{2}{*}{\multicolumn{1}{|c|}{ Items }} & \multicolumn{2}{|c|}{ Frequency } & \multicolumn{2}{c|}{$\begin{array}{c}\text { Percentage } \\
\text { of teachers }\end{array}$} & \multicolumn{2}{c|}{$\begin{array}{c}\text { Percentage } \\
\text { of cases }\end{array}$} \\
\cline { 2 - 7 } & Czech R. & Poland & Czech R. & Poland & Czech R. & Poland \\
\hline $\begin{array}{l}\text { Unified commu- } \\
\text { nication instru- } \\
\text { ment for all the } \\
\text { students }\end{array}$ & 25 & 26 & 62.5 & 56.5 & 56.8 & 38.2 \\
\hline $\begin{array}{l}\text { Various methods } \\
\text { of electronic com- } \\
\text { munication with } \\
\text { the teacher or in } \\
\text { the study group }\end{array}$ & $\mathbf{1 0}$ & $\mathbf{2 6}$ & $\mathbf{2 5 . 0}$ & $\mathbf{5 6 . 5}$ & $\mathbf{2 2 . 7}$ & $\mathbf{3 8 . 2}$ \\
\hline $\begin{array}{l}\text { I do not use elec- } \\
\text { tronic communi- } \\
\text { cation }\end{array}$ & $\mathbf{5}$ & $\mathbf{1 6}$ & $\mathbf{1 2 . 5}$ & $\mathbf{0 . 0}$ & $\mathbf{1 1 . 4}$ & $\mathbf{0 . 0}$ \\
\hline $\begin{array}{l}\text { Examination of } \\
\text { suggestions and } \\
\text { preferences of } \\
\text { students in the } \\
\text { field of electronic } \\
\text { communication }\end{array}$ & $\mathbf{4}$ & $\mathbf{0}$ & $\mathbf{1 0 . 0}$ & $\mathbf{3 4 . 8}$ & $\mathbf{9 . 1}$ & $\mathbf{2 3 . 6}$ \\
\hline Total & 44 & 68 & 110.0 & 147.8 & 100.0 & 100.0 \\
\hline
\end{tabular}

Source: own elaboration.

The respondents in the Czech Republic could choose more than one of the four possible answers. However, they mostly chose only one of them. The results prove that the teachers prefer a unified communication instrument for communication with their students (62.5\% of all teachers). Moreover, $25 \%$ of all teachers prefer various methods of electronic communication with the teacher or in the study group, which the students can choose. Every tenth teacher would choose the way of communication based on students' preferences.

The academic staff of the University of Silesia prefer two forms of network communication: "unified communication instrument for all the students" and "various methods of electronic communication with the teacher or in the study group" (each entry: 56.5\% of all teachers). The number of choices of the preferred form of network communication "examination of suggestions and preferences of students in the field of electronic communication" is not small either - it was declared by $34.8 \%$ of the respondents. None of the respondents in Poland declared not using electronic communication with students. 
Statistical analyses (Fisher's Exact Test) confirmed significant differences between the choices of Polish and Czech scholars in their declarations concerning the preferred form of network communication with students:

- various methods of electronic communication with the teacher or in the study group $-56.5 \%\left(\chi^{2}=8.7 ; \mathrm{p}=0.003\right.$ and $\left.\Phi=0.32\right)$,

- I do not use electronic communication- $0.0 \%\left(\chi^{2}=6.1 ; \mathrm{p}=0.02\right.$ and $\Phi=0.27$,

- examination of suggestions and preferences of students in the field of electronic communication $-34.8 \%\left(\chi^{2}=7.4 ; p=0.006\right.$ and $\left.\Phi=0.29\right)$.

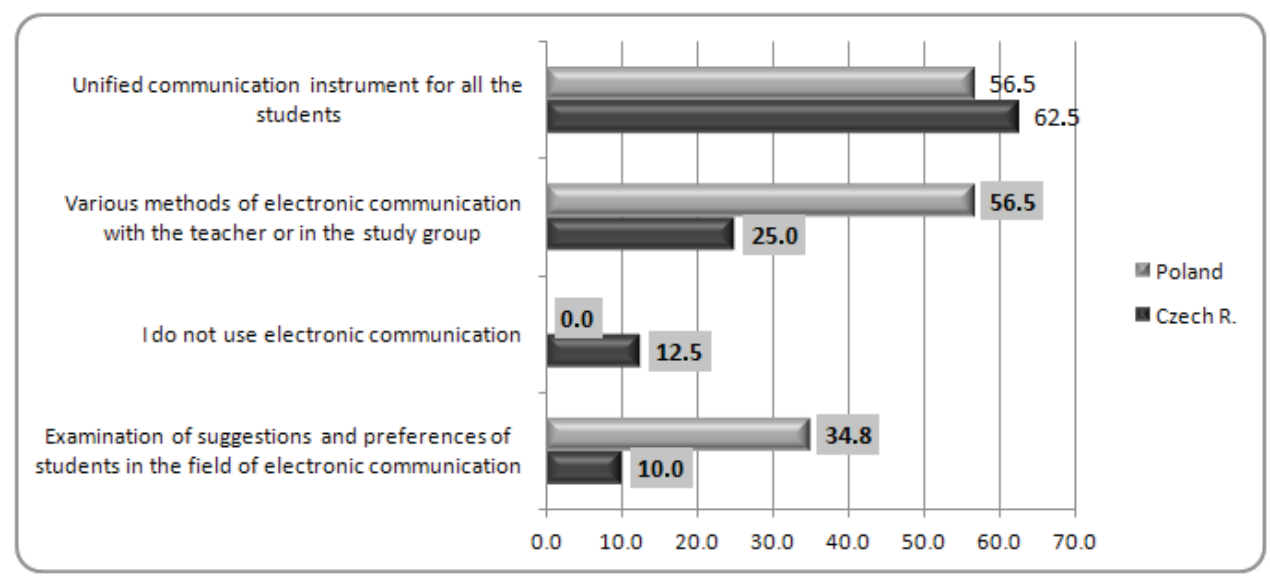

Fig. 2. Teachers' preferred ways of electronic communication with their students (factor - environment)

Source: own elaboration.

The obtained results confirm that academic teachers from Cieszyn use, in their didactic process, all possible forms of network communication with students and that they apply these forms significantly more often than scholars from Ostrava.

The research also involved an attempt at specifying the respondents' preferences in the area of ensuring the best form of learning, owing to which electronic resources will be useful for all students. Some interesting results are presented in Table 3 and Figure 3, respectively.

An important feature of university studies was incorporated into this question - offering all students equal opportunities and conditions for personalized learning. The respondents could choose more than one of the five possible answers. The teachers chose 1-2 answers (65 chosen variants altogether). A slight majority of teachers (55\%) consider offering all students the same set of 
tools to be the best way to ensure that the electronic resources are useful to all students. Half of the teachers consider that the best way of providing students with electronic resources is the one that takes students' knowledge and skills into account. The question is whether this possibility is realistic or theoretical, considering that the adaptive or personalized systems of online education are in the phase of being transferred from theoretical solutions to practical applications). Nearly one third of all teachers (30\%) stated that it would be best if electronic resources could take students' learning styles into account. The comment made for the previous answer also concerns this answer. The answers show that university teachers reflect current principles of respective educational policy and are able to imagine their application in the research field.

Table 3

Preferences concerning the best way to ensure the usefulness of electronic resources to all students (factor - environment)

\begin{tabular}{|l|c|c|c|c|c|c|}
\hline \multirow{2}{*}{\multicolumn{1}{|c|}{ Items }} & \multicolumn{2}{|c|}{ Frequency } & \multicolumn{2}{c|}{$\begin{array}{c}\text { Percentage } \\
\text { of teachers }\end{array}$} & \multicolumn{2}{c|}{ Percentage of cases } \\
\cline { 2 - 7 } & Czech R. & Poland & Czech R. & Poland & Czech R. & Poland \\
\hline $\begin{array}{l}\text { The same set of } \\
\text { electronic resources } \\
\text { for all students }\end{array}$ & 22 & 28 & 55.0 & 60.9 & 33.8 & 23.3 \\
\hline $\begin{array}{l}\text { Electronic resourc- } \\
\text { es reflecting the } \\
\text { knowledge and } \\
\text { skills of students }\end{array}$ & $\mathbf{2 0}$ & $\mathbf{3 6}$ & $\mathbf{5 0 . 0}$ & $\mathbf{7 8 . 3}$ & $\mathbf{3 0 . 8}$ & $\mathbf{3 0 . 0}$ \\
\hline $\begin{array}{l}\text { Electronic resour- } \\
\text { ces reflecting the } \\
\text { learning styles of } \\
\text { students }\end{array}$ & 12 & 18 & 30.0 & 39.1 & 18.5 & 15.0 \\
\hline $\begin{array}{l}\text { Electronic resourc- } \\
\text { es that help stu- } \\
\text { dents with the se- } \\
\text { lection of resources } \\
\text { in the information } \\
\text { environment }\end{array}$ & $\mathbf{7}$ & $\mathbf{2 0}$ & $\mathbf{1 7 . 5}$ & $\mathbf{4 3 . 5}$ & $\mathbf{1 0 . 8}$ & $\mathbf{1 6 . 7}$ \\
\hline $\begin{array}{l}\text { Electronic resour- } \\
\text { ces for advanced } \\
\text { users }\end{array}$ & $\mathbf{1}$ & $\mathbf{1 8}$ & $\mathbf{2 . 5}$ & $\mathbf{3 9 . 1}$ & $\mathbf{1 . 5}$ & $\mathbf{1 5 . 0}$ \\
\hline Other & $\mathbf{1 0}$ & $\mathbf{1 2 0}$ & 162.5 & 260.9 & 100.0 & 100.0 \\
\hline Total & & & & & & \\
\hline
\end{tabular}

Source: own elaboration. 


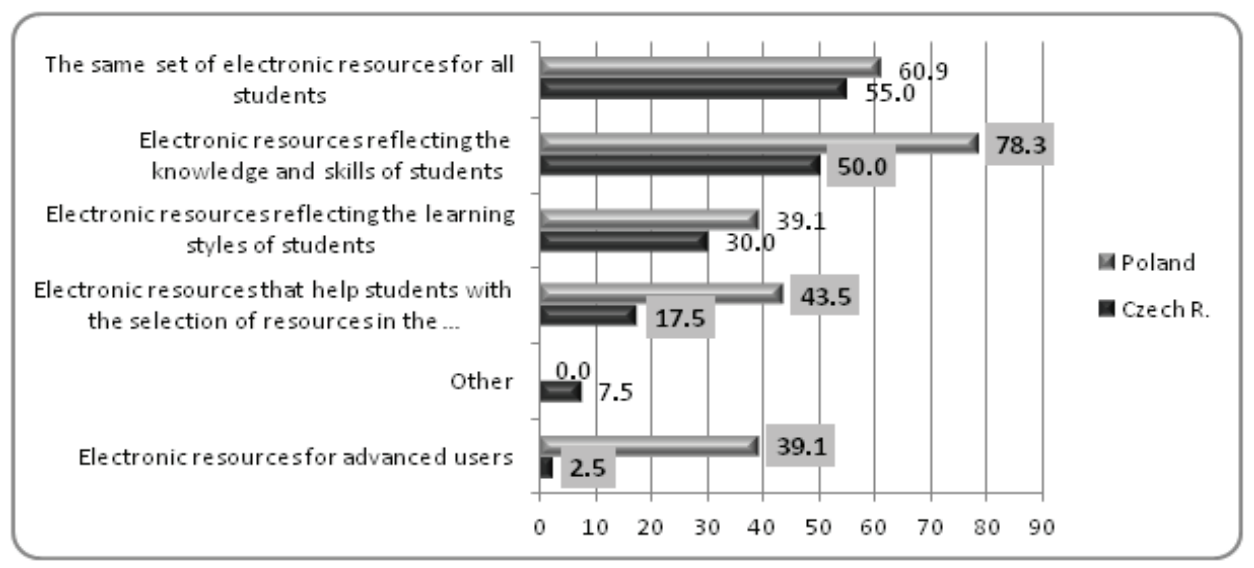

Fig. 3. Preferences concerning the best way to ensure the usefulness of electronic resources to all students (factor - environment)

Source: own elaboration

An in-depth analysis of the data did not show differences between the Czech respondents with regard to their age. However, it showed differences concerning their ICT competence level when choosing the answer that the provided "electronic resources should take students' learning styles into account" (cf. Fig. 4).

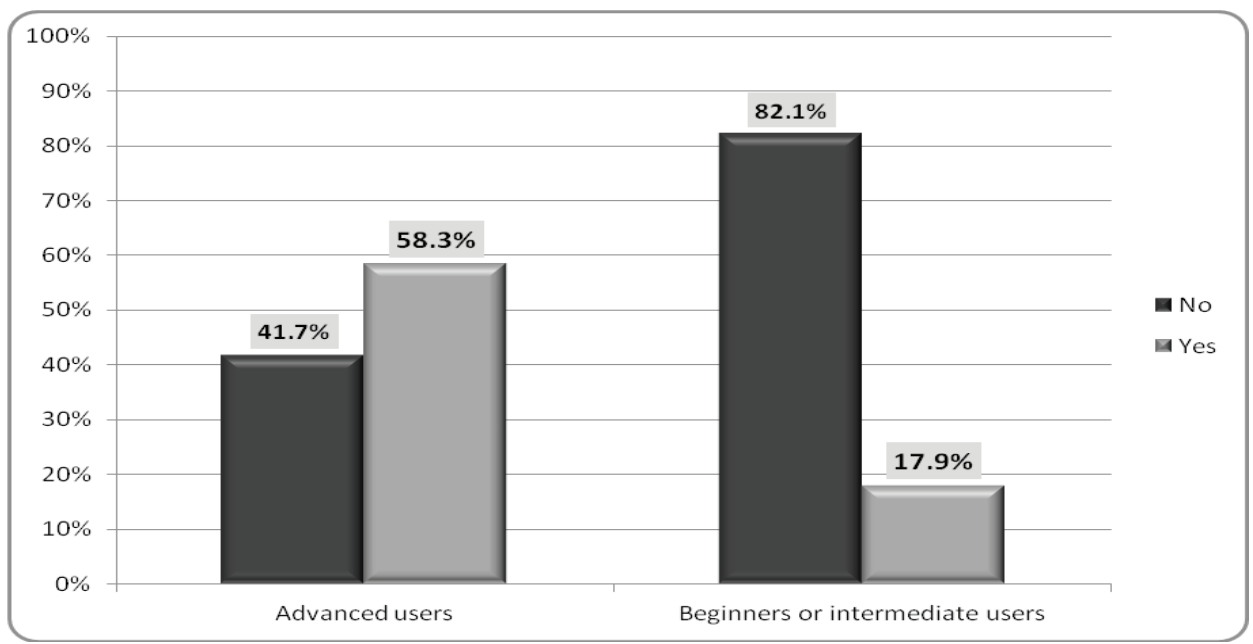

Fig. 4. Influence of teachers' ICT competence on the declarations that the provided electronic resources should reflect students' learning styles (Czech Republic) 
As far as the choice of the entry "electronic resources reflecting students' learning styles" is concerned, a statistically important difference was distinguished between the advanced users and the intermediate users or beginners (Fisher's test significance $=0.028$; chi-squared could not be used due to a high number of expected low frequencies). The advanced users, contrary to the less experienced users, consider this entry to be the best way to ensure that the electronic resources are useful to all students (see Fig. 4). The teachers' ICT user level also seems to represent the level of knowledge concerning the potential of current instruments of electronic systems or environments and the confidence that they can be used in personalized learning which reflects university students' learning style preferences.

The academic staff from the Polish university (60.9\%), like their colleagues from the Czech university, point at the need for the availability of electronic resources to all students. The statistical analyses confirm the lack of significant differences as regards the choice of this category: $\chi^{2}=0.3 ; p=0.37$ and $\Phi=0.06$.

The respondents' declarations pertaining to the entry "electronic resources reflecting the knowledge and skills of students" are positive, but they are more frequent in Poland. This form was chosen by $78.3 \%$ of teachers from the University of Silesia ( $50.0 \%$ among the teachers from Ostrava). The difference is significant, which is confirmed by the analyses (Fisher's Exact Test): $\chi^{2}=$ 7.5; $\mathrm{p}=0.006$ and $\Phi=0.30$.

In Cieszyn, the choice of "electronic resources reflecting the learning styles of students", made by $39.1 \%$ of teachers is similar to the results obtained in Ostrava (30.0\%) and is not statistically significant: $\chi^{2}=0.8 ; p=0.26>p=0.05$ and $\Phi=0.1$. The declarations concerning the entry "electronic resources that help students with the selection of resources in the information environment" made by the staff of the Polish university are more frequent $(43.5 \%)$ than in the case of Czech respondents (17.5\%) and this difference is significant $\left(\chi^{2}=\right.$ 6.7; $p=0.009$ and $\Phi=0.28$ ). In a similar way, the category "electronic resources for advanced users" is more often chosen by the respondents in Cieszyn $(39.1 \%)$ than in Ostrava $(2.5 \%)$. The difference is significant, which is confirmed in statistical analyses: $\chi^{2}=16.7 ; p=0.000$ and $\Phi=0.44$.

Both in the Polish and Czech academic environment, the category "electronic resources reflecting the learning styles of students" was subjected to analysis in regard to ICT competence. The obtained results concerning the choices made by Polish respondents who declared they were "advanced users" and "beginners or intermediate users" are not statistically significant (cf. Fig. 5). 


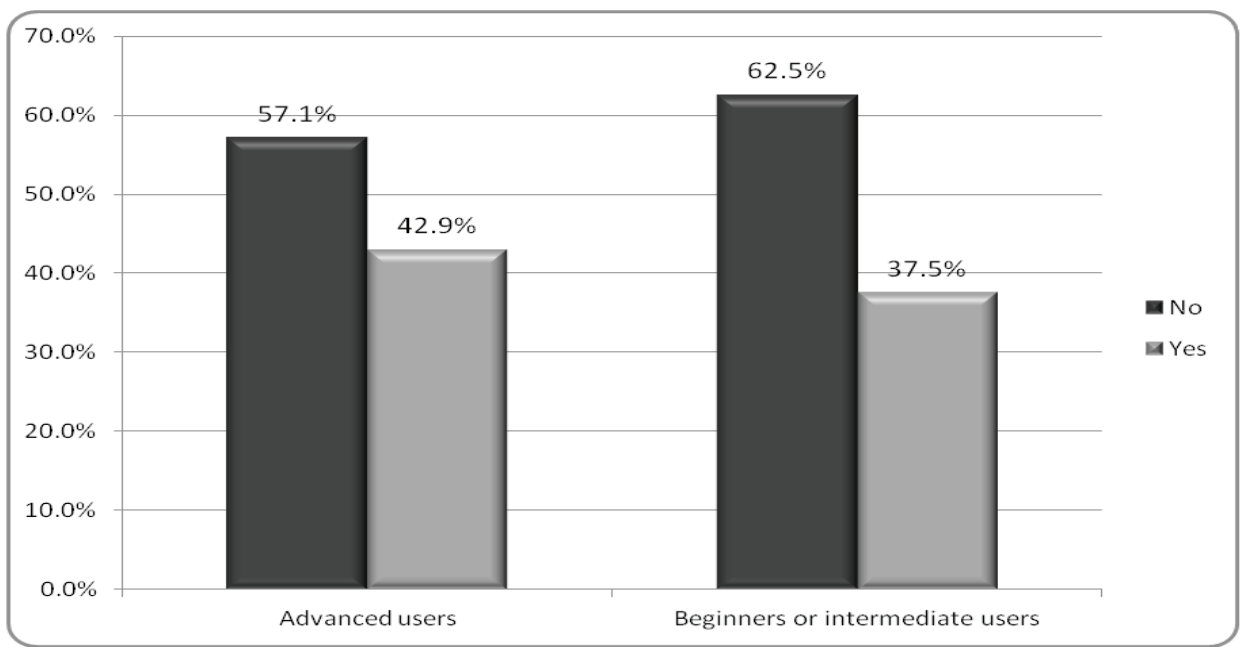

Fig. 5. Influence of teachers' ICT competence on the declaration that the provided electronic resources should reflect students' learning styles (Poland)

Source: own elaboration

\section{Conclusion}

Using new technologies in higher education is inevitable. This significantly changes not only the situation of students but, first of all, of all academic teachers, who are expected to acquire new skills and soft competences. Against the common opinion, the teacher's role in the e-learning system is equally important for learners as in the traditional system. ${ }^{12}$ The academic environment should be aware of the threats posed by implementing classes in the e-learning system ${ }^{13}$, but this is not the reason to resign from such education. E-learning in academic education makes the teacher create a friendly virtual environment, stimulating various activities of students, which enhance e.g. constructing their knowledge or establishing interpersonal relations. Regardless of the obligatory procedures of ensuring the teaching quality (which often inhibit the appearance of new innovative didactic solutions), these are academic teachers who have the direct responsibility for the

12 H.A. Azimi, R. Rahmani, Importance of Needs Assessment for Implementation of e-Learning in Colleges of Education, International Journal of Information and Computation Technology, 2013, 3, 5, p. 377-382.

${ }^{13}$ V. Arkorful, N. Abaidoo, The role of e-learning, the advantages and disadvantages of its adoption in Higher Education, International Journal of Education and Research, 2014, 2, 12, p. 397410 . 
quality of the qualifications they grant and for students' competences, including ICT ones. Thus, they are responsible for their students' learning effects.

As it is emphasized in the Report to the European Commission on New Modes of Learning and Teaching in Higher Education ${ }^{14}$, new technologies and the related didactic methods require a different set of skills than traditional teaching, which might trigger additional pressure on teachers. Not all academic teachers are experts in technology and many have not completed any pedagogical trainings in this field. If their classes are to be of high quality, they need trainings, guidelines and support. This is of particular significance - the application of new ways of teaching results in a change of the role of teachers, from people who pass down the knowledge and are experts in particular fields into mentors and people who encourage students' critical thinking. Moreover, as the results of the latest research of the European Universities Association (EUA) show, a half of higher education institutions have the e-learning strategy but only one fourth makes use of it more extensively. In the same studies it has been indicated that only $12 \%$ of these institutions offer open mass internet courses (MOOC). What is even more interesting is the university staff's attitude to MOOCs: $42 \%$ have no clear opinion on them, $30 \%$ admit to a limited knowledge of them or are not interested in MOOCs, and only $10 \%$ have a positive attitude to such courses (p. 27).

Thus, contemporary universities must, according to Bruner's concept of education, become the so called learning culture. Its fundamental task is supporting students in learning how to use the tools for creating meanings, how to adapt to the world in which they exist, how to change it depending on the needs. Teachers' tasks also involve shaping students' identity and self-esteem as well as increasing their chances for handling the world both at university and outside it. ${ }^{15}$

The comparative studies carried out in Poland and the Czech Republic seem to confirm the differences in the way in which academic teachers evaluate the potentialities of technologies and in which they apply them in educational practice. The effective use of e-learning and modern ICT in universities largely depends on the familiarization with appropriate methodology and knowledge (and the ways of preparing for its application) concerning the use of computers and information technologies. Educators' attitude to teaching in this mode is equally important. In this situation, special significance should be attributed to preparing and implementing programs which support the education and training of academic teachers in the field of applying ICT and e-learning in educational practice.

${ }^{14}$ Report to the European Commission on New Modes of Learning and Teaching, p. 31.

${ }^{15}$ J. Bruner, The culture of education, Cambridge - London 1996, p. 43. 
Acknowledgement. The research leading to these results has received, within the framework of the IRNet project, funding from the People Programme (Marie Curie Actions) of the European Union's Seventh Framework Programme FP7/2007-2013/ under REA grant agreement No: PIRSESGA-2013-612536.

\section{BIBLIOGRAPHY}

Arkorful V., Abaidoo N., The role of e-learning, the advantages and disadvantages of its adoption in Higher Education, International Journal of Education and Research, 2014, 2, 12.

Azimi H.A., Rahmani R., Importance of Needs Assessment for Implementation of e-Learning in Colleges of Education, International Journal of Information and Computation Technology, 2013, 3, 5 .

Bruner J., The culture of education, Harvard University Press, Cambridge - London 1996.

Gajdzica A., Ogrodzka-Mazur E., Chmura M., Malach J., Research into students' ICT competencies and their use in ICT at selected universities. A Polish-Czech comparative study, Studia Edukacyjne, 2015, 36.

Illeris K., Towards a contemporary and comprehensive theory of learning, International Journal of Lifelong Learning, 2003, 22, 4.

Jelonek D., Nowicki A., Ziora L., The Application of e-Learning in the Didactic Process at the Faculty of Management in Czestochowa University of Technology, Organization, Tools, Model, in Cohen, [in:] Proceedings of Informing Science \& IT Education Conference (InSITE), Ed. E. Boyd, Published by The Informing Science Institute Santa Rosa, California 2014.

Koller D., What We're Learning from Online Education? 2012, http:/ /www.ted.com/talks/ daphne_koller_what_we_re_learning_from_online_education [access: 15.03.2018].

Lunenburg F.C., Constructivism and Technology: Instructional Designs for Successful Education Reform, Journal of Instructional Psychology, 1998, 25, 2.

Malach J., Kostolánová K., Chmura M., Ogrodzka-Mazur E., Szafrańska-Gajdzica A., Social media at Czech and Polish universities: a comparative study, International Journal of Information and Communication Technologies in Education, 2016, 5, 1.

Marshall J., Introduction to Comparative and International Education, Sage Publications, Los Angeles - London - New Delhi - Singapore - Washington 2014.

Midgley S., What is Distance Learning? 2016 http://www.thecompleteuniversityguide. co.uk/distance-learning/what-is-distance-learning/ [access: 15.03.2018].

Moore M.G., Anderson W.G. (Eds.), Handbook of distance education, Lawrence Erlbaum Associates, Mahwah, London 2003.

Noah H.J., Eckstein M.A., Dependency Theory in Comparative Education: Twelve Lessons from the Literature, [in:] Theories and Methods in Comparative Education, Eds. J. Schriewer, B. Holmes, Peter Lang Publishers, Frankfurt am Main 1988.

Ogrodzka-Mazur E., Szafrańska A., Malach J., Chmura M., The use of e-learning resources by academic teachers - a Polish-Czech comparative study, The New Educational Review, $2017,50,4$.

Ogrodzka-Mazur E., Szafrańska A., Malach J., Chmura M., Supporting the learning of Polish and Czech students by digital tools, The New Educational Review, 2018, 51, 1.

Powell A. et al., iNACOL Blending Learning Teacher Competency Framework 2015 http:// www.inacol.org/resource/inacol-blended-learning-teacher-competency-framework/ [access: 15.03.2018]. 
Report to the European Commission on New modes of learning and teaching in higher education, Publications Office of the European Union, Luxembourg 2014.

Ryan A., Tilbury D., Flexible Pedagogies: preparing for the future, The Higher Education Academy, New York 2013.

Shapiro B.L., What children bring to light. A constructivism perspective on children's learning in science, Teachers College Press, New York 1994.

Sołtysiak W., Wybrane metody kształcenia stosowane w e-learningu akademickim [Selected educational methods applied in academic e-learning], Podstawy Edukacji [Fundamentals of Education], 2014, 7.

Sołtysiak W., Determinanty aktywności studentów w kontekście ksztatcenia e-learningowego [Determinants of students' activeness in the context of e-learning], Zeszyty Naukowe Politechniki Częstochowskiej. Zarządzanie [Scientific Booklets of Częstochowa University of Technology. Management], 2016, 1, 23. 